\title{
Synthesis and Molecular Structure of (1,3-Dimethyl-4,5-dimethylimidazol-2-ylidene)Ag(I)(benzoate)
}

\author{
Minchul Chung \\ Electromic Haterials Team, Samsung Fine Chemicals Rod C 'enter; \\ 103-I Moonj-Dong, Iusung-(Hu, Daejeon 305-380, Korea \\ Received Iarch 1 t, 2002
}

Key words: Silver, N-Heterocyclic carbene, Benzwate, Cry stal structure

Silver. which has a bulk resistivity of $1.59 \mu \mathrm{Scm}$ is the most conductive of all the metals and for this reason is potentially useful for high-speed microelectronics applications. For example, silver films on semiconductor device materials such as $\mathrm{Si}$ and $\mathrm{SiO}_{2}$, are formed by chemucal vapor deposition (CVD) of silver(l) carbosy lates. ' Various silver(I) carboxylates are readily synthesized from the reaction of $\operatorname{Ag}\left(\mathrm{NO}_{3}\right)$ with carboxylic acid ${ }^{-}$Whitcomb. et al reported that the normal coordination sphere of the silver carboxylates comprises an eight-membered ring in which two silver atoms are bridged by the carboxylates ${ }^{\text {it. } 3 c}$ Recently, Brammer. et $\mathrm{al}^{3 .}{ }^{30}$ reported that silver carboxylate dimers which are further coordinated by two neutral ditopic ligands gave the new building (square $\rightarrow 2 \mathrm{D}$-network) through self-assembly of $\mathrm{Ag}_{2}\left(\mathrm{RCO}_{2}\right)_{2}$. Meanwhile. $\mathrm{N}$-heterocyclic carbenes are two-coordinate carbon compounds that have two nonbonding electrons and no formal charge on the carbon. ${ }^{+}$These micleophilic carbenes, Lewis bases. can be used as ligands in organometallic chemistry: The carboxylate Ag(l) carbene complex is one of the candidates for CVD- and spin-onglass ( $\mathrm{SOM}$ ) precursor. This paper describes the synthesis and the molecular stnicture of an $\mathrm{Ag}(\mathrm{I})$ complex derived from (1.3-dimethyl-4.5-dimethylimidazol-2-ylidene) Ag(1). complex 1. with a benzoate.

\section{Experimental Section}

All the manipulations of air-sensitive compounds were performed under $\mathrm{N}_{2}$ atmosphere, using the standard Sclulenk technique. Solvents were distilled from Na-benzophenone or $\mathrm{CaH}_{2}$. Elemental analy sis was carried out by KRICT. FABMS was carried out by KBSl. 1,3-dimethyl-t.5-dimethylimidazol-2-ylidene ligand ${ }^{\text {ta,6 }}$ and benzoate-silver complex ${ }^{2}$ were prepared according to the literature method.

Synthesis of complex 2: To a Scluenk flask containing pheny lacetonate-silver complex 1 (819 mg. $3.5 \mathrm{mmol}$ ) was added toluene $50 \mathrm{~mL}$ and 1.3-dimethyl-t.5-dimethylimidazol-2-ylidene ( $404 \mathrm{mg}, 3.25 \mathrm{mmol}$ ) in that order at room temperature. The reaction insoluble of complex 1 with 1.3-dimethyl-4.5-dimethylimidazol-2-ylidene gave soluble desired product. After stirring for $1 \mathrm{hr}$. the reaction mixture was evaporated under vacuum and the residue was dissolved in dichloromethane. The resulting solution was filtered with celite pad and the filtrate was exaporated. The crude product was washed with hexane. Recrystalization from dichloromethane/toluene/hexane gave pale yellow crystals of complex 2 (975 mg. $2.76 \mathrm{mmol} .85 \%$ ).

${ }^{\mathrm{l}} \mathrm{H}-\mathrm{NMR}\left(\mathrm{CD}_{2} \mathrm{Cl}_{-}\right): 3.70\left[\mathrm{~s}, 6 \mathrm{H} . \mathrm{N}-\mathrm{CH}_{3}\right] .2 .10[\mathrm{~s}, 6 \mathrm{H} . \mathrm{C}-$ $\mathrm{CH}_{3}$ ], 7.38, 8.00 [m. 5H, Ph]. ${ }^{15} \mathrm{C}-\mathrm{NMR}\left(\mathrm{CD}_{2} \mathrm{Cl}_{2}\right): 176.9$ [s. O-C(O)-Ph]. 173.0 [s, Centrene]. 126.2 [s, $\mathrm{C}=\mathrm{C}\left(\mathrm{CH}_{3}\right)-\mathrm{N}$ ], $136.7,130.8,130.3 .128 .2$ [m. Ph], 36.9 [s. N-C.H ${ }_{3}$ ], 9.5 [s, $\left.\mathrm{C}=\mathrm{C}\left(\mathrm{CH}_{3}\right)-\mathrm{N}\right], \mathrm{FT}-\mathrm{R}(\mathrm{KBr}): 1630.1595 .1553,1397 \mathrm{~cm}^{-1}$. FAB-MS (m/z): $354.9[\mathrm{M}-\mathrm{H}]^{-}$. E.A. for $\mathrm{C}_{14} \mathrm{H}_{17} \mathrm{O}_{2} \mathrm{~N}_{2} \mathrm{Ag}$ : Anal. (Cald): C. 47.88 (47.54): H. 4.81 ( 4.85$)$.

$\mathrm{X}$-ray Structure Determination. Crystal data: $\mathrm{AgC}_{1 .}$ $\mathrm{H}_{1}-\mathrm{N}_{2} \mathrm{O}_{2}: H_{r}=353.17$, orthorhombic, space group Phca, $a=$ $11 .+37(5) . h=8.149(3) . c=31.351(12) \mathrm{A} . \mathrm{r}^{\prime}=2922(2) \mathrm{A}^{3} .7$ $=8 . D_{.}=1.379 \mathrm{~g} \mathrm{~cm}^{-3 .} . F(000)=1424 . \mu(\mathrm{Mo}-\mathrm{K} \alpha)=1.379$ $\mathrm{mm}^{-1} \cdot \mathrm{R}_{\mathrm{l}}=0.059 . \mathrm{w} \mathrm{R}_{\mathrm{z}}=0.149$ for 2242 reflections $\left[\left|\mathrm{F}_{0}\right|>\right.$ $\left.2 \sigma\left(\mathrm{F}_{\mathrm{o}}\right)\right]$.

The pale yellow single crystal was obtained from dichloromethane/toluene/hexane at $-30^{\circ} \mathrm{C}$. A single crystal suitable for structure determination was selected and mounted on a glass fiber tip. The diffraction data for the single crystal of this compound were collected at $298 \mathrm{~K}$ with a Bruker SMART CCD area detector diffractometer with graphitemonochromated Mo-K $\alpha$ radiation $(\lambda=0.71073 \mathrm{~A}$ ) using $\omega$ scans with a scan width of $0.3^{\circ}$ and a scan time of 5 sec per frame. Cell parameters were determined and refined using SMART software. raw frame data were integrated using SAINT programs, Empirical absorption correction was applied with the program SADABS. ${ }^{\varphi_{n}}$ The data were corrected for $I_{p}$ effects. but no correction for crystal decay was applied. The structure of the compound was solved and refined with SHELXS-97. ${ }^{\text {in }}$ Non-hydrogen atoms were refined by full-matrix least-square techuiques with anisotropic displacement parameters. All hydrogen atoms were refined with isotropic displacement parameters. Cnstallographic data for the structure reported here have been deposited with the Cambridge Crystallographic Data Centre (Deposition Nos. CCDC-185703). This data can be obtained free at whiccalcam.ac.uk conts retrining hml.

\section{Results and Discussion}

1.3-Dimethỵl-4.5-dimethylimidazol-2-ylidene reacted 
smoothly with benzoate-silver complex 1 at room temperature in toulene to afford the corresponding complex 2 , a pale yellow, air-stable solid, in good yield (Scheme I).

The reaction is easily confirmed by the ${ }^{-} \mathrm{H}-\mathrm{NMR}$ complex 2, which shows shifted-methyl peaks $\left(\mathrm{C}-\mathrm{C}\left(\mathbf{C H}_{s}\right)\right.$ in imidazolylidene ligand. The solid state structures of the complexes have been deduced from IR spectral inlormation, with the most valuable data being the carbon-oxygen vibrations. $^{3 a} 10$ Where the acetate is monodendate the divergence of $v_{\text {astmm }}\left(\mathrm{CO}_{2}\right)$ and $v_{\text {sym. }}\left(\mathrm{CO}_{2}\right)$, compared with the free ion, is $170 \mathrm{~cm}^{-1}$ up, and its divergence in bidendate complex is $120-150 \mathrm{~cm}^{-1}$. $\wedge$ divergence of $v_{\text {ass } y m}\left(\mathrm{CO}_{2}\right)$ and $v_{5 y \mathrm{~m}}\left(\mathrm{CO}_{2}\right)$ is expected due to a loss of equivalence of the $\mathrm{C}-\mathrm{O}$ bonds. ${ }^{\text {is }}$ $\wedge$ stretching band of the $\left.\mathrm{VCO}_{2}\right)$ group of complex 2 appeared at 1595 (asymetric) and 1397 (symmetric) $\mathrm{cm}^{-1}$. The large IR $\Delta\left(v_{\text {assm }}\left(\mathrm{CO}_{2}\right)-v_{\text {sym. }}\left(\mathrm{CO}_{2}\right), 198 \mathrm{~cm}^{-1}\right)$ values are indicative of monodendate acetate groups. The following discussion on the strueture should hold true for complex $\mathbf{2}$. 'II-NMR spectrum of methyl peaks in imidazolylidenemoiety in complex 2 appeared at $\delta 3.70,2.10$.

In the ${ }^{13} \mathrm{C}-\mathrm{NMR}$, the $\mathrm{C}(2)$ carbon of the earbene ring shifted substantially uplicld by ca. $39.7 \mathrm{ppm}$ in complex 2 .
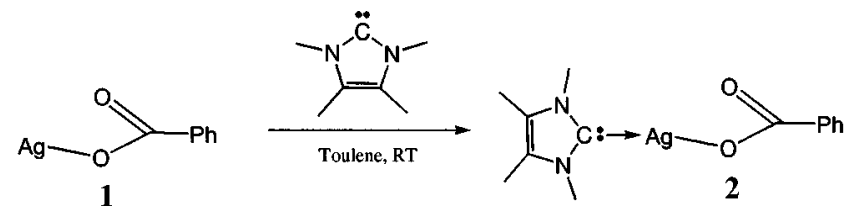

Scheme 1

Table 1. Crystal data and strueture refinement for complex 2

\begin{tabular}{|c|c|}
\hline F:mpirical formula & $\mathrm{C}_{14} \mathrm{H}_{17} \mathrm{Ag} \mathrm{N}_{2} \mathrm{O}_{2}$ \\
\hline Formula wejght & 353.17 \\
\hline 'Temperalure & $293(2) \mathrm{K}$ \\
\hline Wavelenglh & $0.71073 \AA$ \\
\hline Crystal sysiem. space group & Orthorhombic. $\mathrm{Pbca}$ \\
\hline \multirow[t]{3}{*}{ Unit cell dimensions } & $a=11,437(5) \wedge$ \\
\hline & $b=8.149(3) \dot{\lambda}$ \\
\hline & $c=31.351(12) \AA$ \\
\hline Volume & $2922(2) k^{3}$ \\
\hline \%. Calculaled density & $8.1 .600 \mathrm{gim}^{3}$ \\
\hline Absomplion coefficient & $1.379177^{-1}$ \\
\hline $\mathrm{F}(000)$ & $1+424$ \\
\hline Theta range for datati collection & $1.30 \mathrm{to} 27.99 \mathrm{deg}$ \\
\hline I.jmiting indices & $\begin{array}{l}-10 \leq 17 \leq 14 .-9 \leq k \leq 10 . \\
-40 \leq 1 \leq 35\end{array}$ \\
\hline Reflections collectedinnique & $171573361|\mathrm{R}(\mathrm{int})=0.0544|$ \\
\hline Completeness to thela $=27.99$ & $95.3 \%$ \\
\hline Absomplion correction & None \\
\hline Retüement method & Full1-matrix least-squares on $\mathrm{F}^{2}$ \\
\hline I)ata/restrantsiparamelers & $3361 / 0 / 230$ \\
\hline Goodnessis-of-lit on $\mathrm{F}^{2}$ & 1.105 \\
\hline Final $R$ indices $|I>2 \sigma(1)|$ & $\mathrm{RI}=0.05 \%, \mathrm{R} 2=0.149$ \\
\hline $\mathrm{R}$ indices (atl data) & $\mathrm{R} 1=0.097 . \sharp \mathrm{R} 2=0.181$ \\
\hline lixtiuction coeflicient & $0.0096(8)$ \\
\hline I argest dill. peak and hole & 2.278 and -1.027 e. $\AA^{-3}$ \\
\hline
\end{tabular}

Table 2, Selected Bond lengths $[\Lambda]$ and angles [deg] for complex 2

\begin{tabular}{llll}
\hline $\mathrm{Ag}(1)-\mathrm{C}(9)$ & $2.064(6)$ & $\mathrm{Ag}(1)-\mathrm{O}(1)$ & $2.115(5)$ \\
$\mathrm{Ag}(1)-\mathrm{Ag}(1)+1$ & $3.2177(13)$ & $\mathrm{O}(1)-\mathrm{C}(7)$ & $1.273(9)$ \\
$\mathrm{O}(2)-\mathrm{C}(7)$ & $1.228(8)$ & $\mathrm{N}(8)-\mathrm{C}(9)$ & $1.339(7)$ \\
$\mathrm{N}(8)-\mathrm{C}(12)$ & $1.382(7)$ & $\mathrm{N}(8)-\mathrm{C}(14)$ & $1.447(8)$ \\
$\mathrm{C}(9)-\mathrm{N}(10)$ & $1.347(7)$ & $\mathrm{N}(10)-\mathrm{C}(11)$ & $1.384(7)$ \\
$\mathrm{N}(10)-\mathrm{C}(13)$ & $1.467(8)$ & $\mathrm{C}(11)-\mathrm{C}(12)$ & $1.340(9)$ \\
$\mathrm{C}(11)-\mathrm{C}(16)$ & $1.487(9)$ & $\mathrm{C}(12)-\mathrm{C}(15)$ & $1.491(9)$ \\
& & & \\
$\mathrm{C}(9)-\mathrm{Ag}(1)-\mathrm{O}(1)$ & $165.2(2)$ & $\mathrm{C}(9)-\mathrm{Ag}(1)-\mathrm{Ag}(1)+1$ & $69.99(15)$ \\
$O(1)-\mathrm{Ag}(1)-\mathrm{Ag}(1)+1$ & $115.41(15)$ & $\mathrm{C}(7)-\mathrm{O}(1)-\mathrm{Ag}(1)$ & $111.4(5)$ \\
$O(2)-\mathrm{C}(7)-\mathrm{O}(1)$ & $124.9(6)$ & $\mathrm{O}(2)-\mathrm{C}(7)-\mathrm{C}(1)$ & $120.6(6)$ \\
$O(1)-\mathrm{C}(7)-\mathrm{C}(1)$ & $114.5(6)$ & $\mathrm{C}(9)-\mathrm{N}(8)-\mathrm{C}(12)$ & $110.9(5)$ \\
$\mathrm{C}(9)-\mathrm{N}(8)-\mathrm{C}(14)$ & $124.9(6)$ & $\mathrm{C}(12)-\mathrm{N}(8)-\mathrm{C}(14)$ & $124.2(5)$ \\
$\mathrm{N}(8)-\mathrm{C}(9)-\mathrm{N}(10)$ & $104.9(5)$ & $\mathrm{N}(8)-\mathrm{C}(9)-\mathrm{Ag}(1)$ & $124.9(4)$ \\
$\mathrm{N}(10)-\mathrm{C}(9)-\mathrm{Ag}(1)$ & $130.2(4)$ & $\mathrm{C}(9)-\mathrm{N}(10)-\mathrm{C}(11)$ & $111.0(5)$ \\
$\mathrm{C}(9)-\mathrm{N}(10)-\mathrm{C}(13)$ & $124.6(6)$ & $\mathrm{C}(11)-\mathrm{N}(10)-\mathrm{C}(13)$ & $124.3(5)$ \\
$\mathrm{C}(12)-\mathrm{C}(11)-\mathrm{N}(10)$ & $106.2(5)$ & $\mathrm{C}(12)-\mathrm{C}(11)-\mathrm{C}(16)$ & $131.7(6)$ \\
$\mathrm{N}(10)-\mathrm{C}(11)-\mathrm{C}(16)$ & $122.0(6)$ & $\mathrm{C}(11)-\mathrm{C}(12)-\mathrm{N}(8)$ & $106.9(5)$ \\
$\mathrm{C}(11)-\mathrm{C}(12)-\mathrm{C}(15)$ & $130.7(7)$ & $\mathrm{N}(8)-\mathrm{C}(12)-\mathrm{C}(15)$ & $122.4(7)$ \\
\hline
\end{tabular}

Symmetry transformations used to generate equivalent atoms: $-y_{,}-t^{+}+$.

This upfield shilt is consistent with that reported for arylsubstituted carbene silver complex, complex 3 ," with the magnitude being almost the same (cf. $\Delta \delta 41.1$ for complex 3 relative to free aryl-substituted carbene ${ }^{4 c}$ ). The ${ }^{13} \mathrm{C}$ resonance in 2 for $\mathrm{C}(4,5)$ shilted downfield by $3.65 \mathrm{ppm}$ relative to the free carbene, similar to the behavior complex 3.

$\Lambda$ single crystal suitable for $\mathrm{X}$-ray diffraction studies was grown by cooling at $-30{ }^{\circ} \mathrm{C}$ in a dichroromethane/toluenc/ hexane solution of complex 2 . The molecular structure of $\mathbf{2}$ with its atomic numbering scheme is shown in Figure 1. Details on crystal data and intensity are given in Table I. The selected bond distances and bond angles are shown in Table 2. The acetate chelate ring is asymmetrical. The $\Lambda \mathrm{g}(\mathrm{l})-\mathrm{O}(\mathrm{l})$ bond distance, 2. 115(5) $\Lambda$, is slightly shorter than the typical 2.20-2.54 $\AA$ found in common $\left[\left.\Lambda g\left(\mu-\mathrm{O}_{2} \mathrm{CR}\right)\right|_{2}\right.$ carboxylate dimers $^{3.3 .3 \mathrm{in}}$ and $\mathrm{I}(\mathrm{L}) \wedge \mathrm{g}\left(\mu-\mathrm{O}_{2} \mathrm{CR}\right)$. L: Lewis base carboxylate monomers. ${ }^{3-1}$ The other $A g(1)-O(2)$ distance in the chelate ring is a long 2.911 (5) $\Lambda$ because the oxygen, $O(2)$, is not bridged to the silver atom. The crystal packing struclure observed in complex 2 shows that the monomeric units are atranged one above the other, and the distance between the two silver metals, $\mathrm{Agl} \cdots \mathrm{Ag} \mathrm{I}$, which is

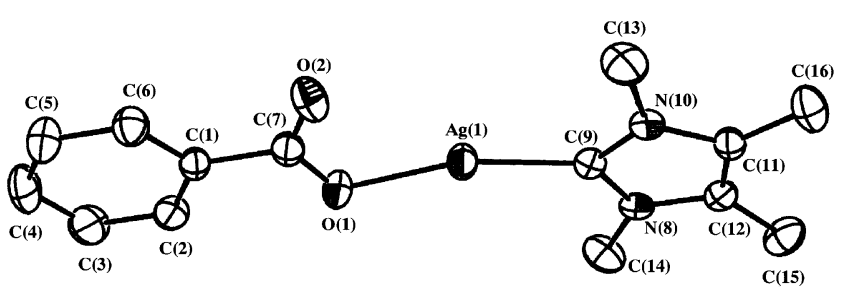

Figure 1. ORTEP drawing of 2 showing the atom-labeling scheme and $30 \%$ probability thermal ellipsoids. Ihe hydrogen atoms are omilted lor clarity. 
$3.2177(13) \mathrm{A}$, is similar to the $3.122(1)$ found in the terminally bound $\left[\mathrm{Ag}_{9}\left(\mathrm{O}_{2} \mathrm{CCH}_{3}\right)_{4}\left(\mathrm{PPh}_{3}\right)_{4}\right]$ complex. This distance is too long for significant interaction to occur between the metals.

The Ag-carbene bond length was $2.06+$ (6) A which is almost the same bond lengths of biscaibene silver complex ${ }^{11}$ : $2.067(4), 2.078(4) \mathrm{A}$. The bond lengths of $\mathrm{C}(9)-\mathrm{N}(8), \mathrm{C}(9)-$ $\mathrm{N}(10)$, which were $1.339(7)$ and $1.347(7)$ A. respectively, are within the expected range and comparable with those found in imidazol-2-ylidene ligands (1.3+-1.37 A). The bond length of $\mathrm{C}(11)-\mathrm{C}(12)$ of $1.340(9) \mathrm{A}$ is a carbon-carbon double bond. The FAB-MS spectrum of the product mixture is dominated by the complex 2 ion, $[\mathrm{M}-\mathrm{H}]^{\prime}$, at $\mathrm{m} / \mathrm{z} 354.9$.

Supplementary Material. Tables of full bond distances and bond angles. atomic coordinates and equivalent isotropic displacement parameters, anisotropic displacement parameters. and torsion angles are available from the author.

Acknowledgment. The author would like to thanks Prof. Y. K. Do. Department of Chemistry at Korea Advanced lnstitute of Science and Teclunology (KAlST). for his assistance with the $\mathrm{X}$-ray crystallography analy sis.

\section{References}

I. Baum, T. II.: Comita, P. B. The (hemisty of Hetal (IT): Kodas. T. l'.. Hampden-Smith. M. J.. Eds.: VCH: New York. U. S. A.. 1994: $\mathrm{p} 303$

2. (a) Wakeshima. 1: Ohgi. H.: Kijima. I. Swhh. React. Morg. Wet-Org. (7tem. 1993, 23(9), 1507. (b) Xu. C.: Corbitt, T. S.: I Iampden-Smitl, M. J.; Kodas, T. T.; Duesler, Г. N. $J$. (Them. Soc. Dalfon Trans. 1994, 2841.

3. (a) Edwards. D. A.: Lomgley. M. J. Inorg. Huct. Chem. 1978. 40. 1599. (b) Whilcomb. D. R.: Rogers. R. D. J. Chem. Chst. 1995. 25(3). 137. (c) Whitcomb. D. R.: Rogers. R. D. J. Chem. Crrst.. 1996, 26(2), 99. (d) No. S. W: Othman. A. II. Acta (ryst. 1997. C53, 1.396. (c) Ng. S. W: Othman, A. II. . Lcto (ryst. 1998. ('5t. 74.3. (f) Ianna. J. V: No. S. W. Icta (ryst. 2000. (56. 24. (g) Brammer. L.: Burgard. M. D.: Rodger. C. S.: Swearingen. „. K.:
Rath, N. P. Chem Comm. 2001. 2486 .

4. (a) Arduengo III. A. I.: I Iarlow, R. I.: Kline. M. $J$. im (hem. Soc. 1991. $113,3(11$. (b) Arduengo III. A. J. LSP 5.077.+14. 1991. (c) Arduengo III. A. I.: Dias. H. V. R.: Harlow. R. L.: Kline. M. J. Am. Chem. Soc 1992. 114. 5530, (d) Arduengo [II. A. J.: Dias. H. V. R.: Dixon. D. A.: Harlow. R. L.: Klooster. W. T': Koetzle. I. F. J. Am. (hem. (hem. 1994, 116. (1812. (c) Arduengo III, A. I.: Goerlich, J. R.: Marshall, W. J. J. Am. (Them. Soc. 1995, /17. I1027. (t) Arduengo III, $\Lambda$. I.: Daridsott. F.: Dais, H. V. R.: Goerlich. J. R:: Khasinis. D.: Mashall. W. J.: P'rakasha. T. K. J. Am. Chem. Soc, 1997. 119. 12742. (g) Arduengo Ill. A. J.: Davidson. F.: Kratezyk. R.: Marshall. W. I,: Tamm. M. Orgemometatlics 1998. 17. 3375. (h) Arduengo III. A. J.: Kraticzyk. R.: Schmutzler. R. Tethohedron 1999. 55, 14523. (i) Arduengo III, $\Lambda$. J. Acco. (Tem Res. 1999. 32(11).913.

5. (a) Arduengo III. A. J.: Rasika. H. V.: Davidson. F.: Harlow. R. L. J. Organomet, Chem. 1993. 462. 13, (b) Hermann. W. A.: Runte. O.: Artus. G. J. Organomet. Chem. 1995. $510 . \mathrm{Cl}$. (c) Herman.

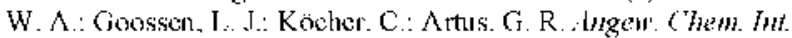
Ed. Fngl. 1996, 35(23:24), 2805. (d) Finders, D.: Criclen. It.: Raabe, G.: Rutnsink. J.: Teles. I. H. Chem. Be\%. 1996. 129. 1483. (e) Hermann. W. A.: Lobmaier. G. L.: Elison. M. J. Orgunometu. Chem. 1996. 520. 231, (1) Köcher. C.: Herman. W. A. J. Organometal. Chem. 1997. 532. 261. (g) Henmam. W. A.: Schwarz. I.: Gardiner, M. G.: Spiegler, M. J. Organometal. ('hem. 1999, 575. 80. (h) Baratta. W.: Herrmann, W. A.: Rigo, P.: Schwarz. J. J. Orgahometal (hem. 2000, 593594 . 489. (i) Hasan. M.: Kozhernikor. I, V.: Siddicui. M. R. H.: Steiner. A.: Winterton. N. J. Chem. Res. 2000. 392. (j) Xu. L.: Chen. W.: Xiao. J. Orgamometallics 2000. 19.1123.

6. Kuhn, N.: Kratz. T. Synthesis 1993. 561.

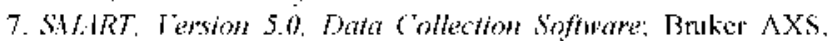
Inc: Madison. WI. 1998.

8. S.HA7. Iersion 5.0. Data Integration Sofnume: Bruter AXS. Inc.: Madison. WI. 1998.

9. (a) Sheldrick. G. M. S.H.ABS, A Program for Absorption Cowection with the Bruker SHLRT System, Universität Göttingen: Germanly: 1996. (b) Sheldrick. (i. M. SHIT/F17. 97 , Program for the refinement of ('mstal Struthres: Unitersity ot Gotingen: Germany 1997.

10. Oldham. C.: Sanford. W. F. J. Chem. Soc., Dalon 1977. 2068.

11. Arduengo III. A. I.: Dias. H. V. R.: Calabrese. J. C.: Davidson. F. Organometallics 1993. 12. 3405 . 